\title{
An unusual paediatric case of mycotic pulmonary artery aneurysm secondary to staphylococcal skin sepsis
}

\author{
Mansi Verma ำ , Amarinder Singh Malhi, ${ }^{1}$ Sanjeev Kumar, ${ }^{1}$ Sandeep Agarwala ${ }^{2}$
}

${ }^{1}$ Department of Cardiovascular Radiology \& Endovascular Interventions, All India Institute of Medical Sciences, New Delhi, India

${ }^{2}$ Paediatric Surgery, AllMS, New Delhi, India

\section{Correspondence to}

Dr Sanjeev Kumar;

sanjeevradio@gmail.com

Accepted 11 January 2022

Check for updates

(c) BMJ Publishing Group Limited 2022. No commercial re-use. See rights and permissions. Published by BMJ.

To cite: Verma M, Malhi AS, Kumar S, et al. BMJ Case Rep 2022;15:e247711. doi:10.1136/bcr-2021247711

\section{DESCRIPTION}

The child was well till 3 months of age when she developed high grade fever documented upto $102^{\circ}$ and swelling on the right side of neck. Incision and drainage of the swelling was done and antibiotics were prescribed. After 15 days, similar abscesses were noted in bilateral legs with subsequent swelling on the left side of chest. The pus culture from the skin lesions revealed methicillin-resistant Staphylococcus aureus (MRSA) and a diagnosis of disseminated staphylococcal sepsis was made. The blood culture, however, was sterile. The child at 6 months presented with cough and two episodes of massive haemoptysis (about $300 \mathrm{~mL}$ per episode). On examination she was toxic and tachycardic. Respiratory system examination revealed decreased air entry on the right side with crepts in right basal segment. The right leg was swollen with areas of pus drainage. At the time of presentation haemoglobin was $100 \mathrm{~g} / \mathrm{L}$ and $\mathrm{SpO} 2$ was $98 \%$ on room air. Her total leucocyte count was $23000 / \mathrm{dL}$ with raised inflammatory markers ( $\mathrm{C}$ reactive protein: $326 \mathrm{mg} / \mathrm{L}$; procalcitonin $15.5 \mathrm{ng} / \mathrm{dL}$ ). The child received basic respiratory support with vital monitoring. Chest X-ray demonstrated reduced volume of right lung with confluent areas of consolidation and a well-defined round opacity in the medial aspect of right lower zone (figure 1). Her immune work up including serum immunoglobulin level, T cell surface markers and antineutrophil cytoplasmic antibodies (ANCA) profile was negative. Transthoracic echocardiography (TTE) was normal.

Contrast enhanced scan of the chest done to look for the cause of haemoptysis, revealed multiple well-defined cavitary lesions in bilateral lungs. One of the cavitary lesion in right lower lobe had airfluid level with an intensely enhancing ovoid lesion measuring $2 \times 2 \mathrm{~cm}$ in its medial wall with enhancement similar to vascular enhancement suggestive of aneurysm (figure 2). No thrombus, calcification or any imaging feature to suggest rupture were seen. This lesion was seen communicating with a branch from right lower lobe pulmonary artery. No intracardiac shunt was seen in the present case. Antibiotic therapy in form of vancomycin and linezolid was prescribed to the child. However, the presence of haemoptysis as seen in our case denoted instable lesion and warranted early intervention. Embolotherapy could serve as a bridge therapy, but due to adjacent lung involvement in the present case, middle and lower lobe lobectomy of the right lung was performed. The operation was performed

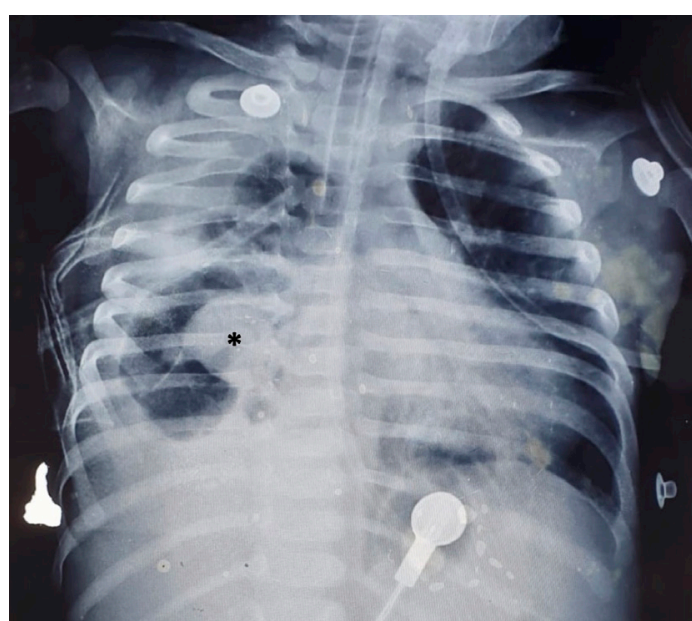

Figure 1 Chest X-ray demonstrates reduced volume of right lung with confluent areas of consolidation and a well-defined round opacity in the medial aspect of right lower zone (marked with black asterisk).

without complication and the child made an uneventful recovery and was discharged 15 days after surgery. The pathological specimen revealed externally congested pleura. On serial slicing a cystically dilated cavity was identified which was filled with haemorrhage. The lung parenchyma revealed emphysematous changes, patchy chronic inflammation and squamous metaplasia of airways. Adjoining vascular channels were thrombosed, and the thrombi were secondarily infected with acute inflammatory exudate and bacterial colonies.

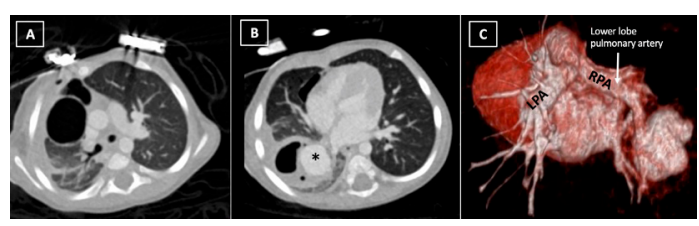

Figure 2 Axial images of chest $(A, B)$ reveal multiple well-defined cavitary lesions with a ovoid intensely enhancing lesion (marked with black * in B) on the medial aspect of right lower lobe lesion with enhancement similar to vascular enhancement suggestive of aneurysm. Fibrotic bands with adjacent ground glass opacities and pleural thickening are noted in right lung. Volume rendered images from posterior view (C) depicting aneurysm from branch of right lower lobar pulmonary artery. RPA: right pulmonary artery; LPA: left pulmonary artery. 
The findings were compatible with pulmonary aneurysm with pneumonitis.

Mycotic aneurysms arising from pulmonary arterial system are rare, with a few cases reported in the literature. Staphylococcal and streptococcus species are the most common causative pathogens as reported in previous case reports. ${ }^{1}$ The mode of spread in the present case can be attributed to endovascular seeding from skin abscesses which is also the most frequent route of transmission. The mycotic pulmonary artery aneurysm in children published in the literature is usually secondary to congenital heart disease as ventricular septal defect, endocarditis and immunosuppression. ${ }^{2}$ However, in the present case staphylococcal skin sepsis was implicated as the cause of pulmonary artery aneurysm which has not been previously described. The

\section{Learning points}

- Mycotic aneurysms arising from pulmonary arterial system are rare and the cause being staphylococcal skin sepsis is rarely described in the literature.

- Pulmonary artery aneurysm should be considered in the differential diagnosis of children presenting with massive haemoptysis and further investigations like chest X-ray and CT angiography are warranted to confirm the diagnosis and to plan further management.

- The presence of predisposing factors like congenital heart disease, endocarditis, immunosuppression and features of sepsis also provide clue in making diagnosis of pulmonary artery aneurysms. prognosis of such aneurysms is dismal with mortality rates of $42 \%-80 \%$ without intervention. ${ }^{2}$ The management of such patients is difficult due to lack of clear guidelines and limited clinical experience. Small aneurysms can be treated conservatively. The presence of haemoptysis as also seen in our case is a significant marker of instability and a strong indicator of prompt intervention. The surgical interventions include aneurysmectomy, lobectomy and pneumonectomy. Less invasive approaches like lobectomy or segmental resection of lung parenchyma if feasible are normally recommended. ${ }^{1}$

Contributors MV: wrote the manuscript. ASM: prepared the manuscript and the images. SK: edited and proofread the manuscript. SA: edited and proofread the manuscript.

Funding The authors have not declared a specific grant for this research from any funding agency in the public, commercial or not-for-profit sectors.

Competing interests None declared.

Patient consent for publication Consent obtained from parent(s)/guardian(s).

Provenance and peer review Not commissioned; externally peer reviewed.

Case reports provide a valuable learning resource for the scientific community and can indicate areas of interest for future research. They should not be used in isolation to guide treatment choices or public health policy.

\section{ORCID iD}

Mansi Verma http://orcid.org/0000-0002-3313-4350

\section{REFERENCES}

1 Benhassen LL, Højsgaard A, Allan Terp K, et al. Surgical approach to a mycotic aneurysm of the pulmonary artery presenting with hemoptysis - A case report and a review of the literature. Int J Surg Case Rep 2018;50:92-6.

2 Bartter T, Irwin RS, Nash G. Aneurysms of the pulmonary arteries. Chest 1988:94:1065-75.

Copyright 2022 BMJ Publishing Group. All rights reserved. For permission to reuse any of this content visit

https://www.bmj.com/company/products-services/rights-and-licensing/permissions/

BMJ Case Report Fellows may re-use this article for personal use and teaching without any further permission.

Become a Fellow of BMJ Case Reports today and you can:

- Submit as many cases as you like

- Enjoy fast sympathetic peer review and rapid publication of accepted articles

- Access all the published articles

- Re-use any of the published material for personal use and teaching without further permission

Customer Service

If you have any further queries about your subscription, please contact our customer services team on +44 (0) 2071111105 or via email at support@bmj.com.

Visit casereports.bmj.com for more articles like this and to become a Fellow 